\title{
FEASIBILITY STUDY ON SOLID WASTE MANAGEMENT IN PORT HARCOURT METROPOLIS: CAUSES, EFFECT AND POSSIBLE SOLUTIONS
}

\author{
C. F. Ikebude

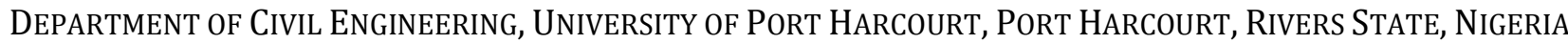 \\ Email address: ddikebude@gmail.com
}

\begin{abstract}
The accumulation of refuse on any place or environment creates fertile breeding ground for rodents, flies, which are disease vectors and also affect the aesthetics of the place, this in turns poses health hazard to the public. In this study, solid waste management in Port Harcourt Metropolis, it causes, effect and possible solutions ranging from waste generation, storage, segregation, collection, treatment and disposal has been investigated. Primary and secondary sources of investigation were used to obtain the required data for the study. Dump sites within the Port Harcourt Metropolis were also visited for proper evaluation and on the spot assessment. It was observed that the conventional waste management system is still being used instead of the integrated solid waste management system (1SWMS) and that about 75\% of the storage facilities in the city are sub-standard and insanitary with no color coded containers for different kinds of waste. Results shows that the composition of waste generated included garbage (41\%), paper and plastic (35\%), scrap metal (15\%), construction waste (4\%), sludge (3\%), expired chemical waste and drugs (2\%) and collection of solid waste at open space transfer station account for about 70\%. These shows poor solid waste management approach and the consequences ranges from aesthetic degradation to pollution of the environment hence the use of solid waste management professionals and sanitarians is recommended.
\end{abstract}

Keywords: Solid waste, pollution, environments, storage facilities and degradation

\section{INTRODUCTION}

Solid wastes are man-made and non-gaseous material. They can simply be said to be residues from domestic, commercial, industrial and agricultural activities [12]. They can also be said to be all waste arising from human and animal activities that are normally solid and are discarded as useless and unwanted. Solid waste if not properly managed and properly disposed can take up reliable space that could have been used for other important purposes; improper disposal causes road blocks, poor aesthetic, constitute serious hindrance to free flow of drainages and can also pollute ground water which can eventually lead to an outbreak of disease, [16]. Unwholesome accumulation of refuse on any place or environment creates fertile breeding grounds for rodents, flies, which are disease vectors and can also affect the beauty of the place which inturns poses health hazard to the entire public.

Waste if not properly managed will also incure excessive cost on the people instead of creating wealth. Human activities can best be carried out in a conducive and clean environment where the wastes generated are well taken care of by proper disposal and management.
Indiscriminate refuse dump also affects the quality of water and air of which most people seem not to be aware. Public education programmes that enlighten the public on the health implications of indiscriminate refuse disposing/dumping are almost non-existent. The menace of solid waste is common to all markets, commercial centre's and most street in Port Harcourt and in the last few decade solid wastes have appeared to be most prominent problem among a score of many problems existing in the metropolis. The magnitude of the solid waste problem is hard to comprehend but can be linked to the increase in population [2]. Population surges have given rise to heavily built up environment wherein houses are most closely built than before, which has then resulted in the dumping of more refuse on the streets and the median of major roads. This is mostly because the waste receptacles located along the highways seems not to be enough. Thousands of life's are lost every year to environmental related diseases. The health implication of improper waste disposal is enormous and cannot be ignored.

Wastes that are not properly managed can cause ground water pollution which leads to diseases like cholera, 
typhoid, dysentery, guinea horn disease. Also certain chemical waste when inhaled in excess or touched can cause wide spread of epidemic, hence a growing global concern about the quality of environment and the need for proper handling and disposal of solid waste.

In order to protect human health and environment from the potential hazards arising from inappropriate waste management and disposal and be able to get the wealth out of our waste, a systematically supervised and controlled management of waste is necessary through government implementations, enforcement and communication.

Agori [3] noted in his work that $87 \%$ of Nigerians practices unsanitary methods of waste disposal which constitute nuisance, ugly sight, produces on pleasant odour and create a breeding ground for pest and diseases. Improper management of waste has resulted in public health issues in other developing countries. Bubonic plague in Europe during the $14^{\text {th }}$ century was due to mountain garbage in the cities which resulted to $30 \%$ increase in the population of rats. Indiscriminate solid waste disposal is actually a menace and embarrassment to the nation where heaps of refuse liter most part of the city. Considerable percentage of unban waste in developing countries is deposited either on the roads, or road sites, on approved dump sites, in water ways, drainage systems, in open sites which adversely affect environmental friendliness. Infact solid waste pose various threat to public health and adversely affect the Funa and Flora as well as the environment when not properly collected and disposed [13].

Solid waste management is the control of solid waste generation, storage, collection, transfer and transport, processing and disposal activities based on engineering principles at minimum environmental impact and with waste generated from household, hospital, industries and commercial centers contribute immensely to environmental obscenity and nuisance, which are hazardous to human existence. These necessitate waste management, which is the act of maintaining acceptable environmental quality, sound public health and creation of atheistic value. It has to do with administration of institution charge with the responsibility of evaluating solid storage from their source of generation through storage, collection, transportation, recovery, treatment processes to disposal.

Dauda, et al [7] stated that waste is the greatest physical problem that persistently poses a great challenge to man on earth and Lee et al [9] has observed that decomposed waste emits carbon dioxide $\left(\mathrm{Co}_{2}\right)$ and methane gas (CHU) which enhances global warming: the problem with waste disposal is multi-facets in nature and can be traced to several factors that includes poor institution framework for waste management by the government, inherent rural attribute of most urban dwellers, poor state of public infective and high urban poverty among others. In adequate funding is another important factor militating or acting as a major problem of waste disposal. The cost of labour, purchase and maintenance of vehicles involved in the collection and disposal of waste has risen so high that many sanitation agencies are already finding it difficult to collect and properly dispose all the collected waste. The main objective of this study is to look at solid waste disposal and management adopted in Port Harcourt Metropolis.

\section{MATERIAL AND METHODS}

\subsection{Study Area}

Port Harcourt is the capital and largest city of Rivers State, Nigeria. It lie along the Bonny River and it is located in the Niger-Delta region. As of 2016, the Port Harcourt urban area has an estimated population of $1,865,000$ inhabitants, up from $1,382,592$ as of 2006. It lies on the $4^{0} 49^{\prime \prime} \mathrm{N} 7021^{\prime \prime} \mathrm{E}$. temperature throughout the year in the city is relatively constant, showing little variation throughout the course of the year. Average temperature is typically between $25^{\circ} \mathrm{C}-28^{\circ} \mathrm{c}$ in the city.

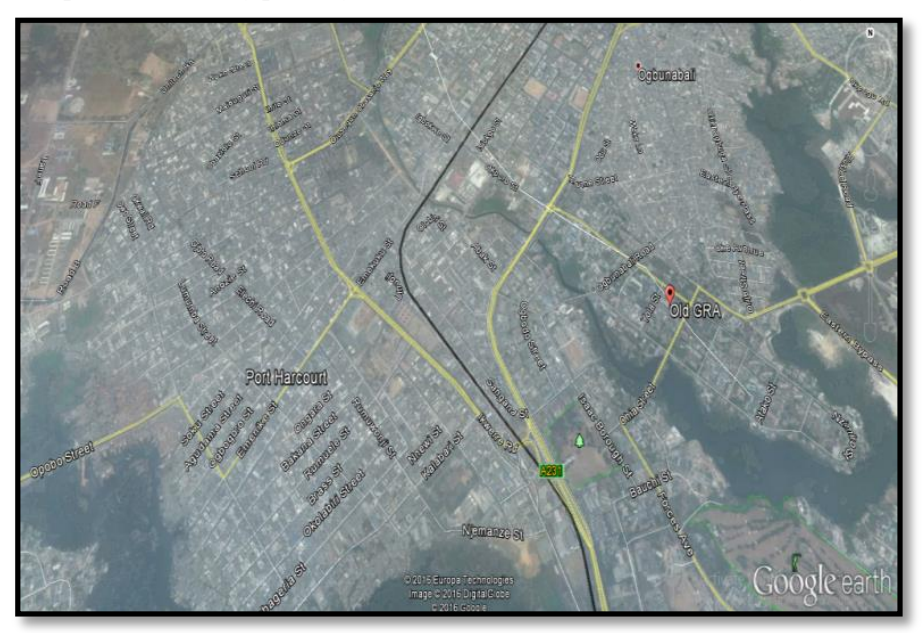

Figure 1.: Map of Port Harcourt

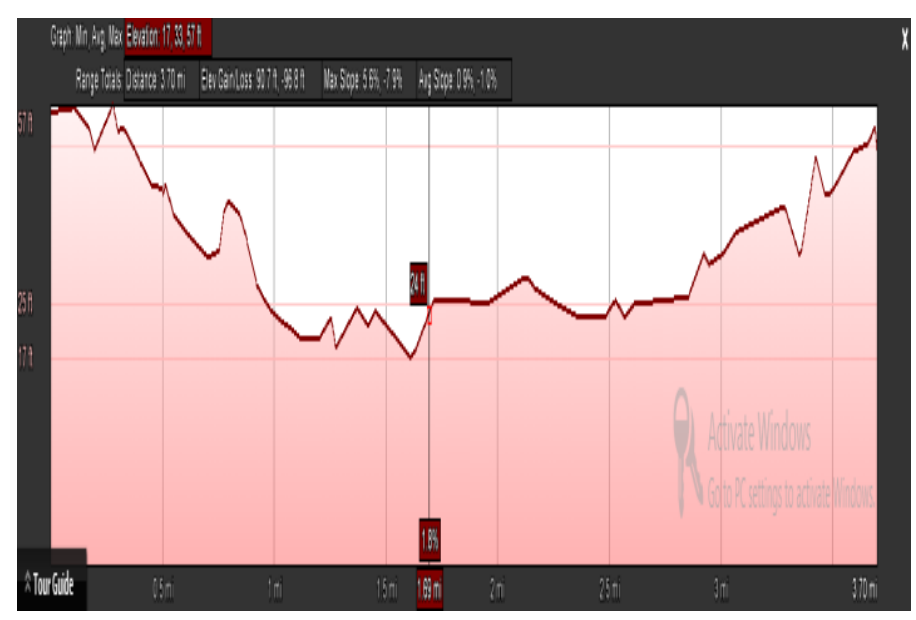

Figure 2: Elevation Profile of Port Harcourt 
Table 1: Values of Elevation Profile

\begin{tabular}{cc}
\hline Parameter & Elevation Values \\
\hline Maximum Elevation & $5.6 \%$ \\
Average Elevation & $0.9 \%$ \\
\hline
\end{tabular}

\subsection{Data Collection}

Data for this study was collected through the use of questionnaires, literature examination, oral interview, field survey and physical observation. In the questionnaire, questions pertaining to age, sex, level of education, occupation, and issues affecting waste collection and disposal operation were asked which account for the primary data used in the study others include, official records from the Rivers-State waste management Agencies(RIWAMA), research project, Articles, which accounts for the secondary data. The secondary data were indeed obtained to ascertain minimum requirement established by government upon which operational approvals or permit were issued. confirm operational compliance with regulations and verify regular environmental status evaluations.

\subsubsection{Sampling Sites and Size}

The sampling site were divided into four (4) key area of the city which includes Borokiri district, Main town district, Diobu District, Government Reserved Area (Old GRA) district. waste collected from each of the district are dumped in either of the dumpsites at Eneka, Oyigbo or Airport road dumpsites based on proximity to the dump site. Stratified random sampling at each of the site was used to ensure appropriate representation of the entire classes in the population. A total 200 respondents were used in the study which was evenly distributed on gender basis.

\subsection{Method of Data Analysis}

Relevant Statistical tools in Microsoft excel was used. The use of tables, pie chart, and bar charts was employed for the data analysis and presentation. Both the descriptive and inferential technique was applied in the data analysis. Descriptively, data was described using tables, frequency, and measure of central tendency. The first hypothesis tested the significant relationship between the volume of waste generated and the health condition of the respondents. To test for this, two questions were drafted into the questionnaire (to know the size of waste collected in the area and to know how often they treat problems relating to indiscriminate disposal of waste in the areas. The second hypothesis was to test for the significant relationship between inadequate waste bin and indiscriminate disposal of waste. This was also carried out by incorporating two questions into the questionnaire to know the numbers of waste bin and factors leading to indiscriminate disposal of waste in the area.

\section{Results and Discussion}

The data obtained through the administration of questionnaires, analysis, and investigations on the problems and prospects of waste disposal in Port Harcourt Metropolis are analyzed using tables, piecharts, bar-charts, frequencies and percentages in this study, three main landfills sites within the study area were visited in order to ascertain the level/standard of the landfills within the Port Harcourt Metropolis. Out of these three landfills visited it was observed that Oyigbo dumpsite has failed and exceeded its capacity, excessive offensive odour due to poor management and treatments. Resident around the area are predisposed to serious health issue due to the offensive odour and so it is not longer under heavy usage on compared to the others. The finding from the studies showed a significant relationship between the volume of waste generated and the health conditions of the respondents. It was clear also that improper disposal of waste is as results of inadequate waste bin in the study area.

The data collected from these dumpsites are clearly presented in table 2 above, it reveals that most dumpsite are not properly managed and residence around the dumpsites are prone to diseases, there are no landfill liner in any of the sites, no leachate pipe, no covers at any of the site, the groundwater and surface water are at the risk of pollution through leaching. Leachate from it dumpsite may either percolate to the ground gaining access to groundwater or may meander its way to the surrounding surface water. Studies also show that they are not treatment, recycling in any of the dumpsites. These factors put together accounts for poor solid waste management in the oil rich city. Studies show that the average daily waste (refuse) generated within the Port Harcourt Metropolis ranges between 900 - 1350 metric tons. The average percentage composition per mass of solid waste generated within the study area is as shown below in Fig 3 .

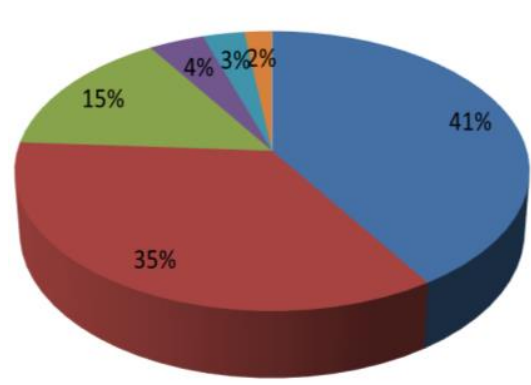

marbage

- Paper and Plastic

Scrap Metal and Glass

- Construction Waste

- Sludge

Fig 3: pictorial presentation of percentage per mass of the physical component of solid waste generated in port-Harcourt Metropolis. 
The pie chart presentation of percentage per mass of the physical component of solid wastes generated in Port Harcourt Metropolis reveals that $41 \%$ accounts for garbage which includes waste food items that decomposes with time, some contains liquids which causes the offensive odour and acts as leachates. The $35 \%$ that accounts for paper and glass are re-cycable if proper measures are put in place, in other words this trash can be turned to treasure. Others include construction waste, sludges, and expired chemical which accounts for less than $10 \%$ of the waste. The types and state of solid waste storage containers used with the study are presented in Table 3 .

Table 3 reveals that only the elite area (Old GRA) have good storage containers with about $72 \%$ containers with covers and $28 \%$ of containers without covers, other area have lesser container with cover. The worst case scenario were recorded in the slum areas of the city Diobu with about $88 \%$ of containers without covers and only $8 \%$ of leak proof containers. This use of labeled containers for different type of waste is not yet a common practice in the oil rich city.

Table 2: Findings from Landfills Sites

\begin{tabular}{|c|c|c|c|c|}
\hline $\mathrm{S} / \mathrm{N}$ & Observation & Eneka landfill & Airport Road landfill & Oyigbo \\
\hline 1 & Landfill liner & Nil & Nil & Nil \\
\hline 2 & Leachate pipe & Nil & Nil & Nil \\
\hline 3 & Landfill gas pipe & Nil & Nil & Nil \\
\hline 4 & Landfill top cover & No top covering & No top covering & No top covering \\
\hline 5 & Waste compactor & $\begin{array}{l}\text { Waste are spread by } \\
\text { bulldozer, no compaction }\end{array}$ & $\begin{array}{l}\text { Waste are spread } \\
\text { bulldozer, no compaction }\end{array}$ & $\begin{array}{l}\text { Waste are not spread presently, no } \\
\text { bulldozers, no compaction }\end{array}$ \\
\hline 6 & FENCE & NO FENCE & NO FENCE & NO FENCE \\
\hline 7 & Nearness to major road. & $100 \mathrm{~m}$ & $10 \mathrm{~m}$ & $5 \mathrm{~m}$ \\
\hline 8 & $\begin{array}{l}\text { Distance from } \\
\text { Residential building }\end{array}$ & $200 \mathrm{~m}$ & $800 \mathrm{~m}$ & $100 \mathrm{~m}$ \\
\hline 9 & Odour & Offensive & Offensive & Very offensive. \\
\hline 10 & Water quality around & Affected & Affected & Affected \\
\hline 11 & $\begin{array}{l}\text { Treatment and } \\
\text { recycling of waste }\end{array}$ & No treatment, no recycling. & No treatment, no recycling & No treatment, no recycling \\
\hline 12 & Landfill supervision & No supervision & No supervision & No supervision \\
\hline 13 & $\begin{array}{l}\text { Environmental status } \\
\text { evaluation }\end{array}$ & Nil & Nil & Nil \\
\hline
\end{tabular}

Table 3: Types and State of Solid Waste Storage containers used is then the study Area

\begin{tabular}{|c|c|c|c|c|c|}
\hline $\mathrm{S} / \mathrm{N}$ & Type/State Containers & Borokiri \% & Main town \% & Diobu \% & Old G.R.A\% \\
\hline 1 & Containers with cover & 25 & 40 & 12 & 72 \\
\hline 2 & Containers without cover & 75 & 60 & 88 & 28 \\
\hline 3 & Leak-proof containers & 16 & 28 & 08 & 50 \\
\hline 4 & $\begin{array}{l}\text { Labeled containers different } \\
\text { kinds of waste }\end{array}$ & 00 & 00 & 00 & 00 \\
\hline 5 & Handled containers & 07 & 11 & 05 & 48 \\
\hline 6 & Stationary containers & 00 & 05 & 00 & 00 \\
\hline
\end{tabular}

Table 4: Approach to Collection and Transfer of Solid Waste within

the Study Area

\begin{tabular}{|c|c|c|c|c|c|}
\hline $\mathrm{S} / \mathrm{N}$ & $\begin{array}{l}\text { Approach to collection and } \\
\text { transfer }\end{array}$ & Borokiri \% & Main town $\%$ & Diobu \% & Old G.R.A \\
\hline 1 & $\begin{array}{l}\text { House to house collection of } \\
\text { waste }\end{array}$ & 00 & 15 & 10 & 98 \\
\hline 2 & $\begin{array}{l}\text { Collection of waste at transfer } \\
\text { station }\end{array}$ & 100 & 85 & 90 & 02 \\
\hline 3 & Daily collection of waste & 40 & 70 & 50 & 80 \\
\hline 4 & Weekly collection of waste & 60 & 30 & 50 & 20 \\
\hline 5 & $\begin{array}{l}\text { Collection and transfer with } \\
\text { compaction trucks }\end{array}$ & 40 & 65 & 30 & 90 \\
\hline 6 & $\begin{array}{l}\text { Collection and transfer with } \\
\text { open trucks }\end{array}$ & 60 & 35 & 70 & 10 \\
\hline 7 & $\begin{array}{l}\text { Well designed and constructed } \\
\text { confined transfer stations }\end{array}$ & 00 & 00 & 00 & 00 \\
\hline 8 & Open space transfer stations. & 100 & 100 & 100 & 05 \\
\hline
\end{tabular}


Table 5: Solids Waste Disposal patterns within the Study Area

\begin{tabular}{llcccc}
\hline S/N & Disposal patterns & Borokiri $\%$ & Main town $\%$ & Diobu $\%$ & Old G.R.A \\
\hline 1 & Dumping into drainages & 05 & 30 & 55 & 00 \\
2 & Dumping into river channels & 60 & 15 & 40 & 30 \\
3 & Dumping on vacant plots & 32 & 15 & 60 & 05 \\
4 & Dumping on public spaces & 05 & 30 & 25 & 15 \\
5 & Dumping at river banks & 65 & 20 & 15 & 05 \\
6 & Burning of waste & 10 & 02 & 05 & 03 \\
7 & Recycling or reuse of waste & 02 & 80 & 80 & 00 \\
8 & Transfer for final disposal & 40 & & & 95 \\
\hline
\end{tabular}

The collection and transfer of solid waste within the study area are most efficient in the old G.R.A. section of the area. House to house collections are practiced on daily basis, this account for a proper management of waste from the area. House to house collection are not practiced at all in Borokiri section and low compliance of the about $10 \%$ in Diobu (slum). Collection of waste at transfer station are prevalent in area where house to house collection are deficient. Table 4 shows the approach to collection and transfer of solid state within the study area.

Generally, the disposal patterns within the study areas are poor which has lead to poor aesthetic and environmental degradation. The most common place for disposal is the public spaces. $60 \%$ of the residents of Diobu dumps their waste in public spaces. In area close to the river like the Borokiri section $60 \%$ of the resident dump their waste into the river. Recycling or re-use of waste is not a common practice. Table 5 shows the disposal pattern within the study area.

\section{WASTE MANAGEMENT SYSTEM IN PORT HARCOURT}

From findings, the conventional method of waste management is adopted in Port Harcourt Metropolis. This method focuses largely/mainly on waste collection, treatment (composting and incineration) and disposal (landfills). From the study, it is clear that the landfill method of waste disposal are not efficient and are below standard. The integrated solid waste management (ISWMS) is recommended to solve the problems of waste management in Port Harcourt Metropolis. This method of solid waste management involves waste reduction at the source, resources recovery and recycling. The resource value of waste cannot be realized unless separation of wastes is practice effectively at the source.

Meanwhile, in many cities in developing countries collection rate remains low and the quality of collection services very poor. Waste collection services are generally non existent in poorer neighborhood such as slum. While there are some successful examples where the private sector are involved in waste management services in many cities of developing countries, involvement of these segment of the society is still very limited. A paradigm shift from the conventional waste management practice to integrated solid waste management system is essential for most cities in developing countries in order to effectively manage the waste. ISWMS is a comprehensive waste prevention, recycling, composting, and disposal programme. It is a better means of effectively protecting human health and environment.

\section{CONCLUSIONS}

The main challenge confronting the global community today is to make the industrial economy more of a closed system. This would save energy, reduce waste and pollution and also minimize cost. In fact, it would enhance sustainability leading to employment generation and cost recovery. Waste generation is a daily affair as such if proper approaches are employed and well managed ought not to pose any problem or challenge to the government. Proper waste management enforcement in Port Harcourt Metropolis cannot be overemphasized, as it is linked with vermin control which is dangerous to health, avoid environmental pollution, creates employment and reveals the beauty of a city. From the finding and results obtained the following conclusions can be drawn.

i. A paradigm shift from conventional waste management practice to integrated solid waste management system (ISWMS) is essential and recommended in order to effectively manage the waste.

ii. Sensitization of Port Harcourt residents on the dangers of poor solid waste management is also necessary because poor waste management practice leads to environmental and health risks as well as losing of economic opportunities in terms of the resource value of their wastes.

iii. Waste bins should in vehicles to stop drivers and passengers from dropping off their waste via the window, which litters the highways.

iv. Waste management courses should be introduced in the school curriculum; this is to create the necessary awareness early enough to school pupils so as to 
address the problem associated with waste from the grass root.

v. Appointment of sanitary /health inspector for the supervision of solid waste management at the home hold level in Port Harcourt City Metropolis.

\section{REFERENCES}

1. Abel, O. A. "An analysis of solid waste generation in a traditional African City". The example of Ogbomosho, Nigeria. Journal of Environmental and sustainability Vol. 20, pp. 20-25. 2009.

2. Abel et al "Estimating the quantity of solid waste generation in Oyo, Nigeria". Waste management and Research, SAGE Journal, PP. 10-12. 2007.

3. Agori, J. E, "Urban solid waste management; A case study of Patani". Master thesis, Submitted to the Department of Civil Engineering, University of Benin. 2010.

4. Agunwanba, J. C. Waste engineering and management tools. Enugu: Immaculate Publications Ltd. 2001.

5. Ajani, O. I. Y, "Determinants of an effective solid waste management in Ibadan Metropolis, Oyo State, Nigeria Journal of food, Agriculture and Environment. Vol. 15, pp 10-12. 2007.

6. Bai, R, \& Sutanto, M. "The practice and challenges of solid waste management in Singapore, waste management; 22:557-567. 2002.

7. Dauda et al. "Solid waste management and reuse in Maiduguri:, Nigeria 29th UEDC International Conference towards the millennium development goal. Abuja. 2003.

8. Egonjobi, T. O. "Problems of solid waste management in Nigerian urban centre", paper presented at the National Conference on Development and the Environment. Organized by MSER, University of Ibadan, Nigeria. 1983.

9. Lee, G. F \&Jones, R. A. "Municipal solid waste management: long term public health and Environmental protection". In NWWA National Outdoor Action Conference on Landfill and Groundwater Quality, LAS Vegan, Nevada. 1991.
10. Igoni, A. H; Ayotamuno, M. J. Ogaji, SOI, \& Robert, S. D. "Municipal solid waste in Port Harcourt, Nigeria. 2007.

11. Kumar, K. N. \& Goel, S. "Characterization of Municipal solid waste (MSW) and a proposed management plan for Kharagpur, West Bengal, India. 2009.

12. Leton, T. G. Water and waste water engineering. The Pearls publishers, Port Harcourt, Rivers State, Nigeria. 2007.

13. Ogwueleke, T. "Municipal solid waste characteristics and management in Nigeria" Iran Journal of Environmental Health Sci. Env. Vol. 10, pp 11-12. 2008.

14. Omuta, G. E. D. "Urban solid waste generation and management; towards an Environmental sanitation policy" in P.O. Sada and F. O. Odemerho (eds), Environmental Issues and Management in Nigerian Development, Evans Brother Ltd (Pub), Ibadan. 1998.

15. Onibokun A. G; Managing the monster: urban waste and governance in Africa. International Development Research Centre, Ottawa. 1999.

16. Oyebola et al "Health implications of solid waste disposal": case study of Olusosun Dumpsite, Lagos Nigeria. International Journal of Pure and Applied Sciences, vol. 12, pp. 17-20. 2009.

17. Walling et al "Municipal Solid waste characteristics and management in developing countries". Nigeria, A case study NTRES 314. 2004.

18. Yusuf, R \& Oyewumi, M. "Qualitative assessment of methane generation potential for municipal solid wastes: A case study. Environmental Research Journal. Vol. 4, pg 5-7. 2008.

19. Zamorano, M. "A planning scenario for the application of geographical information system in municipal waste collection: A case of Churriana de la Vega (Granada, Spain). 2009.

20. Zavodska, A. "A study of residential solid waste composition and management in a selected developing country". Guyana, The Journal of Solid waste management and technology, Department of Civil Engineering Widener University, Chester, U.S.A. Vol. 729, No 1. 2003. 